\title{
Yenidoğan Yoğun Bakım Ünitesinde Viral Alt Solunum Yolu Enfeksiyonu Olan Bebeklerin Değerlendirilmesi
}

\section{Evaluation of Babies with Viral Lower Respiratory Tract Infections in Neonatal Intensive Care Unit}

\author{
Tuba Kasap (0000-0002-6993-8780), Şahin Takcı* (0000-0001-9836-9727), Pelin Özcan (0000-0001-9861-3777) \\ Tokat Gaziosmanpaşa Üniversitesi, Pediatri Anabilim Dalı, Tokat, Türkiye \\ *Ondokuz Mayıs Üniversitesi, Pediatri Anabilim Dalı, Neonatoloji Bilim Dalı, Samsun, Türkiye
}

\begin{abstract}
Anahtar kelimeler
Yenidoğan, alt solunum yolu enfeksiyonu, solunum virüsleri, respiratuvar sinsityal virüs, yenidoğan yoğun bakım
\end{abstract}

\section{Keywords}

Newborn, lower respiratory tract infection, respiratory viruses, respiratory syncytial virus, neonatal intensive care unit

Geliş Tarihi/Received : 03.12.2020

Kabul Tarihi/Accepted : 11.02 .2021

DOI:10.4274/jcp.2021.0015

Yazışma Adresi (Sorumlu Yazar)/Address for Correspondence:

Tuba Kasap, Tokat Gaziosmanpaşa Üniversitesi, Pediatri Anabilim Dalı, Tokat, Türkiye

\section{Öz}

Giriş: Alt solunum yolu enfeksiyonları (ASYE); tüm dünyada çocukluk çağında hastaneye yatış gerektiren ve mortaliteye sebep olan nedenlerin başında gelmektedir. Bu çalışmanın amacı; viral ASYE tanısıyla yenidoğan yoğun bakım ünitesinde (YYBÜ) izlenen hastaların özelliklerinin değerlendirilmesi, viral etkenlerin ortaya konulması ve risk faktörlerinin araştırılmasıdır.

Gereç ve Yöntem: Bu çalışmada; bir üniversite hastanesinde 3. basamak YYBÜ’ye Ocak 2018 ve Mart 2020 tarihleri arasında takip ve tedavi için yatırılıp viral ASYE tanısı koyulan hastaların özellikleri ve solunum yolu viral paneli sonuçları geriye dönük olarak incelendi. Hastalar RSV (+) saptananlar ve RSV-dışı viral etken saptanalar olmak üzere iki gruba ayrıldı ve gruplar karşılaştırıldı.

Bulgular: Çalışmaya 24 hasta dahil edildi. SYVP sonuçlarında $6(\% 25)$ hastada RSV-A, $8(\% 33,3)$ hastada RSV-B, $10(\% 41,6)$ hastada RSV dış1 viral etkenler saptandı. RSV saptanan hastalar ile RSV dışı etkenlerin saptandığı hastalar arasında sosyo demografik özellikler açısından fark bulunmazken; RSV saptanan grupta akciğer grafisinde infiltrasyon varlığı (pnömoni) daha fazla, solunum ya da oksijen desteği alma oranı daha yüksek ve ortalama yatış süresi daha uzun olarak saptandı (p değerleri sırasıyla 0,001,0,001 ve 0,017). Yatış süresi ile C-reaktif protein düzeyi arasında pozitif yönde, orta düzeyde korelasyon saptand 1 ( $\mathrm{r}=0,558$, $\mathrm{p}=0,005)$.

Sonuç: YYBÜ'de viral ASYE'de en sik etken RSV olarak bulunmuştur. $\mathrm{Bu}$ nedenle YYBÜ'de çalışanların hijyen kurallarına çok dikkat etmeleri ve ziyaretçilerin de bu konuda ciddi şekilde eğitildikten sonra YYBÜ ortamına alınmaları vurgulanmalıdır. Viral ASYE düşünülen hastalarda erken tanı-tedavi yapılabilmesi ve hastalığın yayılımının önlenebilmesi için viral testlere ulaşımın artırılması ve testlerin yaygınlaştırılması önem arz etmektedir.

\begin{abstract}
Introduction: Lower respiratory tract infections (LRTIs) are one of the leading cause of hospitalization and mortality in childhood worldwide. The aim of this study was to evaluate the characteristics of the patients hospitalized in the neonatal intensive care unit (NICU) with the diagnosis of viral LRTI, to reveal the viral agents and to investigate the risk factors.

Materials and Methods: In this study; the characteristics and the respiratory tract viral panel results of the patients who were hospitalized in the NICU of a university hospital between January 2018 and March 2020 with the diagnosis of viral LRTI were examined retrospectively. The patients were divided into two groups as RSV $(+)$ and non-RSV viral agents, and the groups were compared.
\end{abstract}


Results: 24 patients were included in the study. RSV-A was detected in $6(25 \%)$, RSV-B in 8 (33.3\%), and non-RSV viral agents in $10(41.6 \%)$ patients. There were no significant difference between the sociodemographic features of RSV (+) group and non-RSV group. However presence of infiltration on chest radiography (pneumonia) was more common, the rate of receiving respiratory or oxygen support was higher and hospitalization duration was longer in RSV (+) group compared to non-RSV group (p values 0.001 , 0.001 and 0.017 , respectively). There was a positively, moderate level correlation between hospitalization duration and C-reactive protein $(\mathrm{r}=0.558, \mathrm{p}=0.005)$.

Conclusions: RSV was the most common agent in viral LRTI in NICU, it should be emphasized that the staff in the NICU should pay close attention to the hygiene rules and that the visitors should be taken into the NICU after they are educated on this issue. It is important to increase the access to viral tests and provide wider use in order to make early diagnosis and treatment in viral LRTI and to take the necessary measures for preventing spread of the disease.

\section{Giriş}

Alt solunum yolları enfeksiyonları (ASYE); tüm dünyada çocukluk çağında hastaneye yatış gerektiren ve mortaliteye sebep olan nedenlerin başında gelmektedir $(1,2)$. İlk iki yaşta solunum yolu enfeksiyonlarının \%80'i viral kökenli olup, bunların da \%40'ını respiratuvar sinsityal virüs (RSV) oluşturmaktadır (3-5). Yenidoğan döneminde de viral etkenlerin önemli olduğu bilinmekte ve son y1llarda geliştirilmiş olan viral testler ile yenidoğanlarda ASYE'de viral etkenler ortaya konulabilmektedir. Özellikle ayaktan başvuran ve ASYE tanısıyla yenidoğan yoğun bakım ünitesine (YYBÜ) yatırılan yenidoğanlarda viral etyolojinin saptanmasi; gereksiz ve uzun süre antibiyotik kullanımının önüne geçilmesi, hastaların izole edilmesi ve hastalığın diğer bebeklere yayılmasının önlenmesi açısından önem arz etmektedir. Bu çalışmanın amacı; viral ASYE tanısıyla YYBÜ'de izlenen hastaların sosyo demografik ve klinik özelliklerinin değerlendirilmesi, etkenlerin ortaya konulması ve risk faktörlerinin araştırılmasıdır.

\section{Gereç ve Yöntem}

$\mathrm{Bu}$ çalışmada; bir üniversite hastanesinde 3 . basamak YYBÜ'ye Ocak 2018 ve Mart 2020 tarihleri arasında takip ve tedavi için yatırılan ve viral ASYE tanısı konulan hastalar geriye dönük olarak incelendi. Merkezimizde; 16 adet üçüncü basamak küvöz, 5 adet ikinci basamak küvöz, 3 izole ve 2 kot yatak mevcuttur ve 'aile-merkezli yenidoğan bakımı' yürütülmektedir. YYBÜ'ye yatırılmış olan viral ASYE tanılı hastaları belirlemek amaciyla hastane otomasyon sisteminde solunum yolu viral paneli (SYVP) hizmet kodu taraması yapıldı ve çalışma tarihlerinde sonucu pozitif bulunanlar belirlendi. Bu hastalar arasından yalnızca evden gelen ve ASYE tanısıyla yatırılan, postmenstürel yaşı 44 haftaya kadar olan prematüreler ile postnatal yaş1 28 güne kadar olan term bebekler dahil edildi. Altta yatan hastalıği (konjenital anomali, kardiyak problem vs.) olan bebekler ve başka bir nedene bağlı YYBÜ'de yatmakta iken SYVP pozitif bulunan hastalar nozokomiyal enfeksiyon düşünülerek çalışma dışında bırakıldı. Hastane otomasyon sisteminden hastaların sosyo demografik özellikleri, başvuru şikayetleri, yatış boyunca klinik bulguları, laboratuvar sonuçları, akciğer grafileri, viral test sonuçları ve yatış süreleri incelenerek kaydedildi.

Merkezimizde ASYE tanısıyla yatırılan tüm bebeklerden kan kültürü, hemogram, C-reaktif protein gibi belirteçler alınmakta, akciğer grafisi çekilmekte ve ampirik antibiyotik tedavisi başlanmaktadır. Ailede yakın zamanda üst solunum yolu enfeksiyonu öyküsü ile hastaların kan kültürleri, laboratuvar sonuçları ve kliniği değerlendirilerek bakteriyel enfeksiyon dışlanan ve viral etyoloji düşünülen hastaların antibiyotikleri erken dönemde kesilmektedir. Ayrıca; viral ASYE düşünülen yenidoğanlarda başvuruda nazofarengeal sürüntü, aspirat ya da endotrakeal aspirat örneklerinden SYVP gönderilmesi rutin bir işlem olarak uygulanmaktadır. Bu panelde; multipleks revers transkriptaz polimeraz zincir reaksiyonu (RT-PCR) yöntemi ile solunum yolu virüslerinden İnfluenza $\mathrm{A} / \mathrm{B}$, İnfluenza $\mathrm{H} 1 \mathrm{~N} 1, \mathrm{RSV} \mathrm{A} / \mathrm{B}$, Parainfluenza 1-4, Coronavirüs (OC43, 229E, NL63, HKU1 tipleri), Rhinovirus/Enterovirüs, Adenovirüs, Human Metapnömovirüs, Bocavirüs tip 1 açısından pozitiflik değerlendirilmektedir.

SYVPsonuçlarına göre hastalarRSV (+) saptananlar ve RSV-dışı olmak üzere iki gruba ayrıldı ve gruplar sosyo demografik özellikler, laboratuvar bulguları ve klinik izlem özellikleri (solunum desteği, oksijen ihtiyacı, yatış süresi gibi) açısından karşılaştırıldı. RSV grubu RSV-A ya da RSV-B saptanan hastalardan oluşmaktaydı, diğer hastalar RSV-dışı grubuna alındı. 
Çalışma için kurumumuz bünyesindeki Etik Kurul Komisyonu'ndan onay alındı.

İstatistiksel analiz için SPSS-20 (Statistical Package for the Social Sciences for Windows) paket programı kullanıldı. Tanımlayıcı istatistiklerde sayı, yüzde, ortalama, standart sapma, minimum ve maksimum değerler kullanıldı. Grupların karşılaştırılmasında iki ortalama arasındaki farkın önemlilik testi ve ki kare analizi kullanıldı. Sayısal değerler arasındaki ilişkiyi incelemek için Pearson korelasyon analizi yapıldı. İstatistiksel testlerin tümünde $\mathrm{p}$ değerinin 0,05 'in altında olması anlamlı olarak tanımlandı.

\section{Bulgular}

Ocak 2018 ve Mart 2020 tarihleri arasında YYBÜ’ye yatırılan 2013 hastanın 105'inde (\%5,2) ASYE tanıs1 mevcuttu. Bu tarihlerde akut viral ASYE düşünülen 54 hastadan toplam 61 SYVP örneği gönderildiği, 26 hastada $(\% 42,6)$ pozitiflik saptandığ görüldü. İki hastada numune hastane yatışı sırasında alındığından bu hastalar çalışmaya dahil edilmedi. Sonuç olarak toplamda 24 hasta çalışmaya alındı ve bu hastaların sosyo demografik özellikleri, klinik ve laboratuvar bulguları ile SYVP sonuçları değerlendirildi.

Hastalarımızın başvurudaki ortalama postnatal yaş $22,2 \pm 7,2$ gündü. Ortalama doğum kilosu $3097 \pm 532$ gr (1750-3900), ortalama doğum haftası 37,9 $\pm 2,1$ $(32-41)$, beş hastada $(\% 20,8)$ prematüre doğum söz konusu idi. Hastalarımızın 13'ü kız idi $(\% 54,2)$. En sık başvuru mevsimi kış, en sık başvuru ayı ise Şubat (6-\%25) ve Mart (6-\%25) ayları idi. Hastaların sosyo demografik özellikleri Tablo 1'de görülmektedir.

Başvuru semptomlarında tüm hastalarda öksürük şikayeti vardı. Buna ek olarak 9 hastada $(\% 37,5)$ burun akıntıs1, $3(\% 12,5)$ hastada ateş, $4(\% 16,6)$ hastada morarma ve $6(\% 25)$ hastada hiriltılı solunum şikayetleri vardı. Laboratuvar bulgularında 5 hastada $(\% 20,8)$ C-reaktif protein (CRP) pozitifliği mevcuttu. Hastalarımızın laboratuvar parametrelerinin ortalama değerleri Tablo 2'de verilmiştir.

Hastalarımızın hepsine ampirik antibiyotik tedavisi başlandığı, 5 hasta dişında erken dönemde (ilk 5 gün içinde) tedavinin kesildiği görüldü. Hastalarımızın hiçbirinde kan kültüründe üreme olmadı.

SYVP sonuçlarında 6 (\%25) hastada RSV-A, 8 $(\% 33,3)$ hastada RSV-B, $10(\% 41,6)$ hastada RSV dış1 viral etkenler saptandı (Tablo 3).

Çalışmamızda RSV saptanan hastalar $(14-\% 58,3)$ ile RSV diş1 etken saptanan hastaların $(10-\% 41,6)$ özellikleri karşılaştırıldı. İki grup arasında sosyo demografik özellikler ve laboratuvar bulguları açısından anlamlı fark görülmez iken RSV saptanan grupta diğer gruba göre akciğer grafisinde infiltrasyon varlığ 1 (pnömoni) daha fazla, solunum ya da oksijen desteği alma oranı daha yüksek ve ortalama yatış süresi daha uzun olarak saptandı ( $\mathrm{p}$ değerleri sırasıyla $0,001,0,001$ ve 0,017 ) (Tablo 4).

Tablo 1. Çalışmadaki hastaların sosyo demografik özellikleri

\begin{tabular}{|c|c|c|}
\hline & Ort \pm SS (Min. - Maks.) & Median \\
\hline Postnatal yaş (gün) & $22,2 \pm 7,2(8-37)$ & 24 \\
\hline Cinsiyet $(\mathrm{K})$ - n (\%) & $13(54,2)$ & - \\
\hline Doğum şekli (NSVY) - n (\%) & $13(54,2)$ & - \\
\hline Doğum kilosu (gr) & $3097 \pm 532(1750-3900)$ & 3192 \\
\hline Doğum haftası & $37,9 \pm 2,1(32-41)$ & 38 \\
\hline Anne yaşı (y1l) & $28,1 \pm 6,3(19-43)$ & 27,5 \\
\hline Evdeki kişi sayısı & $5,1 \pm 1,8(3-10)$ & 5 \\
\hline Kardeş sayı1sı & $1,25 \pm 1(0-4)$ & 1 \\
\hline Evde ÜSYE olan kişi varlı̆̆ı - n (\%) & $15(62,5)$ & - \\
\hline \multicolumn{3}{|l|}{ Başvuru mevsimi - $\mathrm{n}(\%)$} \\
\hline Sonbahar & $4(16,6)$ & \\
\hline Kiş & $11(45,8)$ & - \\
\hline İlkbahar & $9(37,5)$ & \\
\hline Yaz & 0 & \\
\hline
\end{tabular}


Tablo 2. Çalışmadaki hastaların laboratuvar parametreleri

\begin{tabular}{lll}
\hline & $\begin{array}{l}\text { Ort, } \pm \text { SS } \\
(\text { Min, - Maks, })\end{array}$ & Ortanca \\
\hline Beyaz küre sayıs1 $\left(/ \mathrm{mm}^{3}\right)$ & $9371 \pm 2798$ & 9400 \\
& $(2880-14900)$ & \\
ANS $\left(/ \mathrm{mm}^{3}\right)$ & $3625 \pm 2360$ & 3260 \\
& $(230-9030)$ & 5110 \\
ALS $\left(/ \mathrm{mm}^{3}\right)$ & $4805 \pm 1321$ & \\
& $(1560-6410)$ & 1,20 \\
CRP $(\mathrm{mg} / \mathrm{L})$ & $2,6 \pm 3,1$ & 0,73 \\
NLO & $(0,12-12)$ & $0,81 \pm 0,54$ \\
\hline
\end{tabular}

Ort: Ortalama, SS: Standart sapma, Min: minimum, Maks.: maksimum, ANS: Absolü (mutlak) nötrofil sayısı, ALS: Absolü lenfosit sayısı, CRP: C-reaktif protein, NLO: Nötrofil/ lenfosit sayısı oranı.

Tablo 3. Hastalarda saptanan viral etkenlerin dağılımı

\begin{tabular}{ll}
\hline Viral etkenler & $\mathrm{n}(\%)$ \\
\hline RSV-A & $6(\% 20,8)$ \\
RSV-B & $8(\% 29,1)$ \\
Adenovirüs & $1(\% 4,1)$ \\
Coronavirüs-229E & $1(\% 4,1)$ \\
İnfluenza A & $1(\% 4,1)$ \\
İnfluenza-H3N2 & $1(\% 4,1)$ \\
Rhinovirüs & $1(\% 4,1)$ \\
Ko-enfeksiyon & $1(\% 4,1)$ \\
Adenovirüs + Parainfluenza 4 & $1(\% 4,1)$ \\
Coronavirüs NL63 + Human metapnömovirüs & $1(\% 4,1)$ \\
Rhinovirüs + Enterovirüs & $1(\% 4,1)$ \\
Coronavirüs NL60 + Rhinovirüs + Enterovirüs & $1(\% 4,1)$ \\
Adenovirüs + Rhinovirüs + Enterovirüs & \\
\hline RSV: Respiratuvar sinsityal virüs &
\end{tabular}

Çalışmamızda 17 hastanın (\%70) solunum desteği (mekanik ventilasyon) ya da oksijen desteği ihtiyac1 olduğu görüldü. Bir hastaya $(\% 4,1)$ invaziv mekanik ventilasyon, bir hastaya $(\% 4,1)$ ise invaziv olmayan mekanik ventilasyon uyguland, 15 hastaya ise sadece oksijen desteği verildi. Mekanik ventilasyon uygulanan 2 hasta da RSV saptanan grupta idi. Solunum veya oksijen desteği alma ile; kış mevsiminde başvurma ve RSV saptanması arasında anlamlı ilişki olduğu görüldü (p değerleri sırasiyla 0,041 ve 0,001 ), diğer demografik ve laboratuvar bulgular arasında bir ilişki saptanmadi (Tablo 5).
Hastalarımızın ortalama yatış süresi 7,8 $\pm 4,5$ (124) gündü. Yatış süresi ile cinsiyet, doğum şekli, doğum kilosu, doğum haftası arasında anlamlı ilişki bulunmazken laboratuvar parametrelerinden CRP düzeyi ile pozitif yönde orta düzeyde korelasyon saptand $1(r=0,558$. $p=0,005)$. Ayrica RSV saptanan grupta yatış süresi daha uzundu $(\mathrm{p}=0,017)$.

\section{Tartışma}

$\mathrm{Bu}$ çalışmada YYBÜ’ye akut ASYE nedeniyle yatırılan ve viral etken tespit edilen, ek problemi olmayan hastalar değerlendirilmiş, bu hastalarda en sık etkenin RSV olduğu ve RSV saptanan hastaların diğer hastalara göre pnömoni oranının daha yüksek, solunum desteği ihtiyacının daha fazla ve yatış süresinin daha uzun olduğu tespit edilmiştir. Literatürde de RSV'nin bebeklerde en sik ASYE etkeni olduğu belirtilmiştir (1,2,6-8). Okulu ve ark. (6) tarafından yapılan çalışmada YYBÜ'de ASYE nedeniyle yatan hastalarda RSV $\% 80$ ile en sık etken olarak saptanmıştır. Bu oran Cho ve ark.'ın (7) çalışmasında \%80, Bukhari ve ark.'ın (8) çalışmasında ise \%95 bulunmuştur. Tek başına bir etkenin bu kadar büyük bir orana sahip olması alınacak önlemler ve koruma tedavileri açısından bir avantaj olarak düşünülebilir. Bilindiğgi gibi RSV büyük oranda direk temas ve kontamine eşyalarla, az oranda da damlacık yoluyla bulaşmaktadır. Homaira ve ark. (9) tarafından yapılan çalışmada YYBÜ'de RSV'nin ribonükleik asit molekülü ziyaretçilerin kıyafetlerinden ve sık kullanılan yüzeylerden izole edilmiş ve bunun kontaminasyonda önemli olduğu gösterilmiştir. Bu nedenle YYBÜ'de hijyen kurallarının ciddi şekilde 
Tablo 4. RSV saptanan hastalar ile diğer hastaların karşılaştırılması

\begin{tabular}{|c|c|c|c|}
\hline & $\begin{array}{l}\mathrm{RSV}(+) \\
\mathrm{n}=14\end{array}$ & $\begin{array}{l}\mathrm{RSV}(-) \\
\mathrm{n}=10\end{array}$ & $\mathrm{p}$ \\
\hline \multicolumn{4}{|l|}{ Sosyo demografik özellikler (ort \pm ss) } \\
\hline Postnatal yaş (gün) & $20,8 \pm 5$ & $24,3 \pm 9,4$ & 0,259 \\
\hline Cinsiyet $(\mathrm{K})^{*}$ & $9(64,3)$ & $4(40)$ & 0,239 \\
\hline Doğum şekli (NSVY)* & $8(57,1)$ & $5(50)$ & 0,729 \\
\hline Doğum kilosu (gr) & $3200 \pm 387$ & $2953 \pm 684$ & 0,270 \\
\hline Doğum haftası & $38,3 \pm 1,7$ & $37,6 \pm 2,7$ & 0,434 \\
\hline Kardeş sayısı & $1,5 \pm 1,16$ & $0,9 \pm 0,74$ & 0,165 \\
\hline Anne yaşı (yıl) & $28,2 \pm 5$ & $28 \pm 8,2$ & 0,937 \\
\hline Ailede ÜSYE varlığ $1 *$ & $11(78,6)$ & $4(40)$ & 0,054 \\
\hline Evdeki kişi sayısı & $4,8 \pm 1,1$ & $5,6 \pm 2,5$ & 0,291 \\
\hline \multicolumn{4}{|l|}{ Laboratuvar bulguları } \\
\hline Beyaz küre sayısı $\left(/ \mathrm{mm}^{3}\right)$ & $9859 \pm 2747$ & $8689 \pm 2868$ & 0,324 \\
\hline ANS $\left(/ \mathrm{mm}^{3}\right)$ & $4264 \pm 2709$ & $2794 \pm 1573$ & 0,142 \\
\hline $\operatorname{ALS}\left(/ \mathrm{mm}^{3}\right)$ & $5095 \pm 935$ & $4428 \pm 1680$ & 0,238 \\
\hline $\mathrm{CRP}(\mathrm{mg} / \mathrm{L})$ & $2,91 \pm 3,43$ & $2,32 \pm 2,89$ & 0,666 \\
\hline NLO & $0,88 \pm 0,57$ & $0,72 \pm 0,52$ & 0,493 \\
\hline Akciğer grafisinde infiltrasyon varlı̆̆ $1 *$ & $13(92,8)$ & $3(30)$ & $\mathbf{0 , 0 0 1}$ \\
\hline \multicolumn{4}{|l|}{ Klinik izlem } \\
\hline Solunum veya oksijen desteği alan hasta sayısı $*$ & $11(91,7)$ & $1(8,3)$ & 0,001 \\
\hline Yat1ş süresi (gün) $(\mathrm{Ort} \pm \mathrm{SS})$ & $9,64 \pm 4,88$ & $5,3 \pm 2,5$ & $\mathbf{0 , 0 1 7}$ \\
\hline
\end{tabular}

uygulanması ve direk temasin en aza indirilmesi önem arz etmektedir. Özellikle son y1llarda YYBÜ'de kanguru bakımını da kapsayan aile merkezli yenidoğan bakımının yaygınlaştığı düşünüldüğünde RSV'nin yayılımının engellenmesi için çok daha sıkı önlemlerin alınması gerektiği açıktır (10).

Çalışmamızda RSV saptanan hastaların diğer hastalara göre pnömoni oranının daha yüksek, solunum desteği ihtiyacının daha fazla ve yatış süresinin daha uzun olduğu tespit edilmiştir. Okulu ve ark.'nın yaptıkları çalışmada da YYBÜ'de RSV'ye bağlı ASYE ile izlenen bebeklerde yatış süresinin daha uzun olduğu gösterilmiştir (6). Siyah Bilgin ve ark.'ın (11) yaptıkları benzer bir çalışmada ise RSV saptanan grupta RSV dişı virüs saptananlara göre solunum desteği oranının daha fazla olduğu ve RSV'nin solunum desteği ihtiyacı için önemli bir risk faktörü olduğu bulunmuştur. Jung Cho ve ark. (7) da RSV saptanan yenidoğanlarda pnömoninin daha sık, oksijen ihtiyacının daha fazla, yatış süresinin daha uzun olduğunu ortaya koymuşlardır.

Çalışmamızda hastaların en sık Şubat ve Mart aylarında başvurdukları saptandı. Ülkemizde Alan S. ve ark. tarafından ulusal düzeyde yapılan çalışmada da RSV'ye bağlı ASYE nedeniyle yatışların en sık Şubat ayında olduğu saptanmıştır (12). Okulu ve ark. (6) tarafından yapılan çalışmada da RSV enfeksiyonuna bağlı yatışların Şubat ayında zirve yaptığı bulunmuştur.

Bebeklik ve çocukluk döneminde ASYE'de solunumsal virüslerin önemli yeri olduğu bilinmekte ve YYBÜ'de de bu etkenler yaygın olarak görülebilmektedir. ASYE nedeniyle yatırılan yenidoğanlarda rutin laboratuvar testleri ve radyolojik incelemeler ile viral - bakteriyel ayrımı yapılamamakta ve çoğunlukla ampirik antibiyotik tedavisi verilmektedir (10). Bizim çalışmamızda da hastaların hepsine ampirik antibiyotik tedavisi başlandığı ancak izlemde büyük bir kısmında; laboratuvar tetkikleri, 
Tablo 5. Hastaların solunum desteği veya oksijen ihtiyacı olma durumlarını etkileyen faktörlerin değerlendirilmesi

\begin{tabular}{|c|c|c|c|c|}
\hline & & \multicolumn{2}{|c|}{$\begin{array}{l}\text { Solunum desteği veya oksijen ihtiyacı olma durumu } \\
(\text { Ort } \pm \text { SS })\end{array}$} & \multirow[b]{2}{*}{$\mathrm{p}$} \\
\hline & & $(+)$ & $(-)$ & \\
\hline \multicolumn{2}{|c|}{ Postnatal yaş (gün) } & $20,9 \pm 4,7$ & $23,67 \pm 9,1$ & 0,363 \\
\hline \multicolumn{2}{|c|}{ Cinsiyet- $\mathrm{K}^{*}$} & $8(66,7)$ & $5(41,7)$ & 0,219 \\
\hline \multicolumn{2}{|c|}{ Doğum kilosu (gr) } & $3075 \pm 393$ & $3119 \pm 661$ & 0,847 \\
\hline \multicolumn{2}{|c|}{ Doğum şekli- NSVY* } & $8(66,7)$ & $5(41,7)$ & 0,219 \\
\hline \multicolumn{2}{|c|}{ Doğum haftası } & $38,2 \pm 1,7$ & $37,7 \pm 2,5$ & 0,57 \\
\hline \multicolumn{2}{|c|}{ Anne yaşı (yıl) } & $27,3 \pm 4,9$ & $28,92 \pm 7,7$ & 0,555 \\
\hline \multirow{3}{*}{ Mevsim* } & Sonbahar & $0(0)$ & $4(33,3)$ & \multirow{3}{*}{$\mathbf{0 , 0 4 1}$} \\
\hline & Kiş & $8(66,7)$ & $3(25)$ & \\
\hline & İlkbahar & $4(33,3)$ & $5(41,7)$ & \\
\hline \multicolumn{2}{|c|}{ Beyaz küre sayısı $\left(/ \mathrm{mm}^{3}\right)$} & $10028 \pm 2810$ & $8715 \pm 2745$ & 0,26 \\
\hline \multicolumn{2}{|c|}{$\operatorname{ANS}\left(/ \mathrm{mm}^{3}\right)$} & $4318 \pm 2829$ & $2868 \pm 1499$ & 0,145 \\
\hline \multicolumn{2}{|c|}{$\operatorname{ALS}\left(/ \mathrm{mm}^{3}\right)$} & $5074 \pm 1062$ & $4512 \pm 1555$ & 0,319 \\
\hline \multicolumn{2}{|c|}{$\mathrm{CRP}(\mathrm{mg} / \mathrm{L})$} & $3,69 \pm 3,87$ & $1,64 \pm 1,93$ & 0,115 \\
\hline \multicolumn{2}{|l|}{ NLO } & $0,91 \pm 0,62$ & $0,7 \pm 0,46$ & 0,361 \\
\hline \multirow[t]{2}{*}{ RSV } & $(-)$ & $1(8,3)$ & $9(75)$ & \multirow{2}{*}{0,001} \\
\hline & $(+)$ & $11(91,7)$ & $3(25)$ & \\
\hline
\end{tabular}

kan kültürü ve klinik durum değerlendirilerek tedavinin erken dönemde kesildiği görülmüştür ve bu durum literatürle de uyumludur $(10,13)$. Viral etkenin tespiti ve erken tanı; tedavinin düzenlenmesi, gereksiz antibiyotik kullanımının önlenmesi ve özellikle yüksek riskli birçok bebeğin izlendiği YYBÜ'de enfeksiyonun izolasyonunun sağlanabilmesi için son derece önemlidir. Literatürde, kullanımı giderek artan moleküler testlerle viral etkenlerin daha yüksek oranda ortaya konabildiği ve bunun da bakteriyel enfeksiyonlara karşı gereksiz tedavi oranını önemli ölçüde azaltabileceği gösterilmiştir (14). E. GonzalezCarrasco ve ark. (15) tarafından yapılan bir çalışmada burun akıntısı, apne ve yüksek oksijen gereksinimi olan ve sepsis şüphesi olan yenidoğanlarda viral solunum yolu enfeksiyonlarının da akla gelmesi gerektiği vurgulanmıştır. Diğer bir çalışmada ise; odaksız ateş ile başvuran 3 ay altı bebeklerde viral testlerin etiolojiyi aydınlatmak konusunda önemli katkısı olabileceği gösterilmiştir (14). Kidszun ve ark. (10) tarafından yapılan çalışmada; YYBÜ'de klinik kötüleşme gösteren ve geç başlangıçlı sepsis düşünülen yenidoğan bebeklerin bir kısmında kan kültüründe üreme saptanmadi $\breve{g} 1$, nazofaringeal aspiratta solunumsal virüslerin tespit edildiği gösterilmiştir. Çalışmada solunumsal viral enfeksiyonların bakteriyel sepsisi taklit ederek sistemik bir enfeksiyon gibi belirti verebileceği ortaya koyulmuş ve laboratuvar bulgularının viral-bakteriyel nedenler açısından ayırt ettirici olmaması nedeniyle viral testlerin yaygınlaştırılması gerektiği vurgulanmıştır.

\section{Çalışmanın Kısıtlılıkları}

Çalışmamızın en önemli kısıtlılıkları retrospektif olması ve vaka sayısının oldukça az olmasıdır. Ayrıca bir kısım hastalar hafif klinik bulgular ile başvurmuş, ayaktan takip edilmiş ve buna bağlı olarak rakamlara yansımamış olabilir.

\section{Sonuç}

Sonuç olarak YYBÜ'de viral solunum yolu enfeksiyonlarının sık olabileceği bilinmelidir ve erken tanı tedavi yapılabilmesi ve gerekli izolasyon 
önlemlerinin alınabilmesi için viral testlere ulaşımın artırılması ve testlerin yaygınlaştırılması önem arz etmektedir. Özellikle RSV'nin en s1k etken olması nedeniyle YYBÜ'de çalışanların hijyen koşullarına çok dikkat etmeleri ve ziyaretçilerin de bu konuda ciddi şekilde eğitildikten sonra YYBÜ ortamına alınmaları vurgulanmalıdır.

\section{Etik}

Etik Kurul Onayı: Çalışma için kurumumuz bünyesindeki Etik Kurul Komisyonu'ndan onay alındı.

Çıkar Çatışması: Yazarlar tarafından çıkar çatışması bildirilmemiştir.

Finansal Destek: Yazarlar tarafından finansal destek almadıkları bildirilmiştir.

\section{Kaynaklar}

1. Garcia CG, Bhore R, Soriano-Fallas A, Trost M, Chason R, Ramilo $\mathrm{O}$, et al. Risk factors in children hospitalized with RSV bronchiolitis versus non-RSV bronchiolitis. Pediatrics 2010;126(6):e1453-60.

2. Stockman LJ, Curns AT, Anderson LJ, Fischer-Langley G. Respiratory syncytial virus-associated hospitalizations among infants and young children in the United States, 1997-2006. Pediatr Infect Dis J 2012;31:5-9.

3. Heiskanen-Kosma T, Korppi M, Jokinen C, Kurki S, Heiskanen $\mathrm{L}$, Juvonen $\mathrm{H}$, et al. Etiology of childhood pneumonia: serologic results of a prospective, population-based study. Pediatr Infect Dis J 1998; 17:986-91.

4. Hamano-Hasegawa K, Morozumi M, Nakayama E, Chiba N, Murayama SY, Takayanagi N, et al. Comprehensive detection of causative pathogens using real-time PCR to diagnose pediatric community-acquired pneumonia. J Infect Chemother 2008;14:424-32.

5. Karakoyun M, Akıncı Ataoğlu E, Büyükkayhan D, Elevli` M. Solunum yolu enfeksiyonu bulguları ile başvuran 2 yaş altı çocuklarda Respiratuvar sinsityal virüs enfeksiyonlarının sıklığ ve klinik özellikleri. Online Türk Sağlık Bilimleri Dergisi 2018;3:56-69.
6. Okulu E, Akduman H, Tunç G, Çiftçi E, İnce E, Erdeve Ö, ve ark. Viral alt solunum yolu enfeksiyonu nedeniyle yatırılan yenidoğanların epidemiyolojik ve klinik özellikleri. Türkiye Çocuk Hastalıkları Dergisi. 2018;12:31-5.

7. Cho HJ, Shim SY, Son DW, Sun YH, Tchah H, Jeon IS. Respiratory viruses in neonates hospitalized with acute lower respiratory tract infections. Pediatr Int 2013;55:49-53.

8. Bukhari EE, Elhazmi MM. Viral agents causing acute lower respiratory tract infections in hospitalized children at a tertiary care center in Saudi Arabia. Saudi Med J 2013;34:1151-5.

9. Homaira N, Sheils J, Stelzer-Braid S, Lui K, Oie JL, Snelling $\mathrm{T}$, et al. Respiratory syncytial virus is present in the neonatal intensive care unit. J Med Virol 2016;88:196-201.

10. Kidszun A, Klein L, Winter J, Schmeh I, Gröndahl B, Gehring $\mathrm{S}$, et al. Viral Infections in Neonates with Suspected Late-Onset Bacterial Sepsis-A Prospective Cohort Study. Am J Perinatol 2017;34:1-7.

11. Si yah Bilgin B, Yazıcı A, Özkaya Parlakay A, Ünal S. Acute lower respiratory tract infections caused by PCR-proven viruses in the NICU. Türkiye Çocuk Hastalıkları Dergisi 2020;14:16875 .

12. Alan S, Erdeve Ö, Çakır U, Akduman H, Zenciroğlu A, Akçakuş M, et al; Turk NICU-RSV Trial Group. Outcome of the Respiratory Syncytial Virus related acute lower respiratory tract infection among hospitalized newborns: A prospective multicenter study. J Matern Fetal Neonatal Med 2016;29:218693.

13. Verboon-Maciolek MA, Krediet TG, Gerards LJ, Fleer A, van Loon TM. Clinical and epidemiologic characteristics of viral infections in a neonatal intensive care unit during a 12-year period. Pediatr Infect Dis J 2005;24:901-4.

14. Epalza C, Hallin M, Busson L, Debulpaep S, De Backer P, Vandenberg O, et al. Role of Viral Molecular Panels in Diagnosing the Etiology of Fever in Infants Younger Than 3 Months. Clin Pediatr (Phila) 2020;59:45-52.

15. Gonzalez-Carrasco E, Calvo C, García-Garcia ML, Beato M, Muñoz-Archidona C, Pozo F, et al. Viral respiratory tract infections in the neonatal intensive care unit. An Pediatr (Engl Ed) 2015;82:242-6. 